\title{
MEMORY IN MAMMALS: EVIDENCE FOR A SYSTEM INVOLVING NUCLEAR RIBONUCLEIC ACID*
}

\author{
D. J. Alberti \\ Mental Health Research Institute, University of Michigan, Ann Arbor, Michigan, U.S.A.
}

(Received 7 September 1965)

\begin{abstract}
The learning of an avoidance response was confined to one hemisphere in rats by starting cortical spreading depression in the other. Removing the medial (but not anterior or posterior) cortex of the trained hemisphere impairs retention of the learning. If the medial tissue is intraperitoneally injected back into the donor animal, there is savings in relearning with the untrained hemisphere. This savings seems to be specific to the previously learned task and the effect occurs only when the tissue from the trained hemisphere is removed after consolidation of the learning has progressed for several hours. Ribonucleic acid molecules located in the nucleus of some group of cortical cells seem to mediate the savings effect. These results suggest that the effect of injecting the tissue from the trained cortex is to allow ribonucleic acid molecules which have coded the information about the learned response to migrate to the untrained hemisphere and function there as stored learning.
\end{abstract}

\section{INTRODUCTION}

THE changes in the central nervous system which constitute learning have generally been thought to consist of changes limited to the synapse, which alter the functional relations between nerve cells and neural circuits $[8,13,18]$. There are, however, several lines of evidence which suggest that this conceptualization is at least an oversimplification. First, MoRRELL [14] has shown that learning may involve transcortical pathways connecting different parts of the cortex and has concluded that it is unlikely that the changed functional relations between parts of such a complex network could be accounted for by a simple chain of synaptic modifications. More recently, ALBERT $[2,3]$ has shown that the processes which occur during the consolidation, or fixation, of learning in the rat do not suggest that new morphological synaptic changes are being strengthened, but rather that more stable temporary changes, such as new macromolecular templates, are involved in forming the permanent retention mechanisms. Finally, experiments with planaria seem to show that learning in this more primitive species is coded in macromolecules [21].

The present experiments consider the possibility that macromolecular changes are central to the information storage system in the rat brain. The experiments parallel those done with planaria where evidence was found that learning could be transferred chemically by injecting ribonucleic acid from a trained planarian into an untrained planarian [21]. The design of the present experiments is also to transfer stored information chemically, but the transfer is not between animals, but instead, between one hemisphere and the other in the same animal. Such an intraanimal transfer of learning seemed particularly

\footnotetext{
* Most of this work was done at McGill University, Montreal, Canada, where it was supported by a USPH Predoctoral Fellowship to the author. It has also been supported by a grant to the Mental Health Research Institute (NIH M7417-04).

† Postdoctoral fellow.
} 
advantageous because it involves fewer biological assumptions. (Since these experiments were done, however, two reports $[4,7]$ have appeared describing what appears to be interanimal chemical transfer of learning in rats, and these studies will be considered in the discussion.)

Restriction of the learning to one hemisphere is obtained by using cortical spreading depression to make the other hemisphere nonfunctional during training. A simple avoidance task is used which is known from previous experiments to be easily learned when only one hemisphere is functional [2].

The first step in these experiments is to locate the region in the trained hemisphere where the memory of the avoidance response is stored. It is found that a lesion in the medial (but not anterior or posterior) region of the cortex impairs retention, which suggests that the learning may be stored there. To further test the possibility that the learning is stored there and that a chemical storage mechanism is involved, a second experiment is done in which the tissue from the medial cortex is removed and intraperitoneally injected back into the donor animal. When these animals are tested on the avoidance task using the untrained hemisphere, they show savings in relearning while uninjected control animals do not. To demonstrate more clearly that the savings effect is due to the injection of molecules from the trained tissue which have coded the avoidance learning, several additional experiments are presented which show that the savings in relearning is specific to the previously learned task and that the molecules mediating the effect have the characteristics which existing cvidence and intuitive reasoning require for a macromolecular information coding system.

\section{METHOD}

The experiments all follow a single schedule with minor variations. The subjects were naive, male hooded rats weighing 225-275 g from the Quebec Breeding Farm and Maxfield Animal Supply. Cannulas for starting spreading depression were first implanted in the antero-lateral parietal bone over each hemisphere. On the following day (day 1), the animals were trained on an avoidance task while one hemisphere had cortical spreading depression. It is known that spreading depression disturbs the functioning of the affected hemisphere and that with this task, the learning that occurs while one hemisphere is depressed is recorded mainly in the normal hemisphere [2].

On day 2 , the animals were again subjected to surgery and this time the tissue from the medial region of the trained cortex (which seems to be the area storing the learning) was removed. The procedure differs at this point depending on the purpose of the experiment. If the tissue was to be injected back into the animal, it was kept ice cold as it was removed. When surgery was complete, any desired manipulations of the tissue were made and it was then injected intraperitoneally back into the donor animal.

On day 3, the trained hemisphere was depressed and the animal was tested for savings in relearning with the untrained hemisphere. If the injected tissue has no effect, the animal should require as many trials to relearn as in the original learning, but if there is some positive transfer of learning, the animal should relearn in fewer trials. Groups of 6-8 animals were usually sufficient to establish reliable estimates of the effect of the injected tissue.

Most of this procedure has been described in detail previously [2] and will be presented only generally here. Unilateral spreading depression was started and maintaincd for training and testing by 12 per cent potassium chloride $(\mathrm{KCl})$ placed in the polyethylene cannula over one cortex (for details of the cannulas, see ALbERT [2]). The presence of 
spreading depression was confirmed by noting a hypesthesia of the body contralateral to the depressed hemisphere. The $\mathrm{KCl}$ was left in the cannula for as long as spreading depression was wanted on the cortex and then removed by flushing the cannula with sterile 0.9 per cent $\mathrm{NaCl}$.

The avoidance apparatus was a box $(10 \times 36 \times 18$ in. deep $)$ with white and black halves separated by a sliding partition. The animal was first placed in the black side for $1 \mathrm{~min}$, and then placed at the end of the white side, facing the white end. If the animal returned to the black side within $5 \mathrm{sec}$, the trial was counted as an avoidance; if not, the animal was shocked intermittently until it moved to the black side. There was a 1 min. intertrial interval during which the animal remained in the black compartment. This procedure was the same for both the first learning and the test for savings in relearning, except that in the savings test, the animals were purposely shocked as little as possible to avoid making them freeze.

Approximately 15 per cent of the animals were discarded in the course of training and retraining. The major reasons for discarding animals were: too rapid (less than 10 trials) or too slow (more than 30 trials) first learning; development of localized motor seizures which interfered with performance.

\subsection{Removal and handling of tissue from the trained cortex}

Tissue from the trained cortex was removed using a suction technique. A $10 \mathrm{ml}$ syringe provided the suction and an attached 15 gauge curved hypodermic needle (whose diameter [1.75 mm] is about the thickness of the cortex) was worked gently into the brain tissue and, in places, under the skull to remove the cortical tissue. When the lesion was finished, gelfoam was slipped into the empty space.

Figure 1 shows the location and similarity in size of the anterior, medial, and posterior lesions. The lesions frequently removed the underlying white matter (corpus callosum) but seldom invaded other subcortical structures. The medial lesions gave the most important effects and these began 3-4 $\mathrm{mm}$ from the posterior cortical tip and 1-2 $\mathrm{mm}$ from the midline and extended about $4 \mathrm{~mm}$ anterior and laterally to within $1-2 \mathrm{~mm}$ of the rhinal fissure.

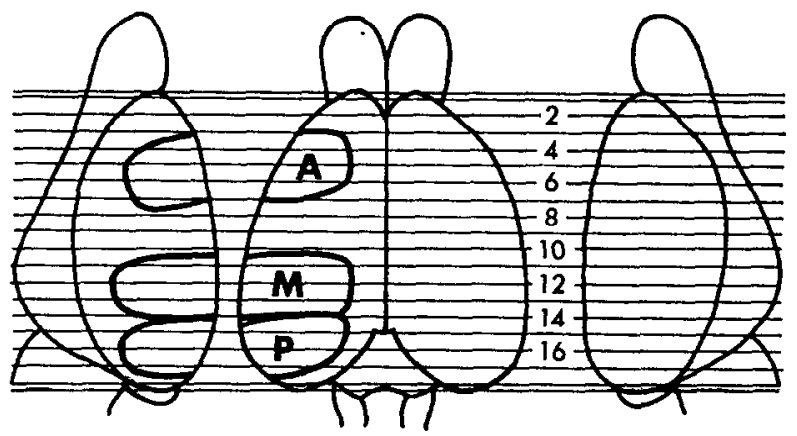

Fio. 1. A Lashley diagram of the rat brain showing the approximate location and size of the unilateral anterior (A), medial (M), and posterior $(P)$ cortical lesions.

If the cortical tissuc was to be injected without any experimental changes, it was placed in about $5 \mathrm{ml}$ of ice cold $0.9 \% \mathrm{NaCl}$ as it was removed. Following surgery, it was broken into small pieces (though this was not necessary) by briefly manipulating it by hand in a 
teflon and glass homogenizer. The tissue was then intraperitoneally injected using a $10 \mathrm{ml}$ syringe and an 18 gauge hypodermic needle, care being taken to avoid getting the fluid into the intestines.

In some experiments, the tissue was separated into subccllular components in order to determine the intracellular location of the molecules causing the savings in relearning. In this case, the tissue was placed in ice cold 0.25 molar (M) sucrose as it was removed and then homogenized using an electric motor drive. To separate the cell nuclei $[9,17]$ the homogenate was layered over $5 \mathrm{ml}$ of $0.32 \mathrm{M}$ sucrose in a $15 \mathrm{ml}$ centrifuge tube and centrifuged for $10 \mathrm{~min}$ at about $800 \mathrm{~g}$ in an International Centrifuge bucket rotor (No. 241). To inject the isolated nuclei, the nuclear pellet on the bottom of the centrifuge tube was resuspended in $5 \mathrm{ml}$ of ice cold $0.25 \mathrm{M}$ sucrose.

To separate the soluble and solid portions of the nuclear fraction, the isolated nuclei were resuspended in distilled water $\left(8 \mathrm{ml}, 0^{\circ} \mathrm{C}\right)$ to break them open. The solid material was then sedimented by centrifuging at $100,000 \mathrm{~g}$ for $60 \mathrm{~min}$ in a Spinco Ultracentrifuge (No. 40 head).

A preliminary identification of the kind of molecules mediating the savings in relearning was established using enzymes which selectively break down certain kinds of molecules. Protein was broken down using trypsin. The trypsin used was sterile, lyophilized, 3 times recrystallized (Worthington Biochemicals). Ribonuclease was used to destroy ribonucleic acid and this was 5 times recrystallized (National Biochemical Company).

\section{RESULTS}

\subsection{The locus of information storage}

The first step in this research is to locate the region in the trained hemisphere where the information about the avoidance response is stored. Previous experiments using the same task seemed to show that if the information is made to transfer from the trained to the untrained hemisphere (by giving the animal one avoidance trial with the trained and untrained hemispheres functional), the information is received in the medial region of the untrained cortex $[2,3]$. It seemed reasonable, therefore, that in the trained hemisphere at least part of the learning is localized in the homotopic medial cortex.

To test this hypothesis, the animals were given a retention test after the medial cortex of the trained hemisphere was removed. The lesions were made on the day after avoidance training, and on the following day, the animals $(N=10)$ were tested for savings in relearning the avoidance task while the untrained hemisphere was nonfunctional with cortical spreading depression. Two control groups of 6 animals each were treated in the same way except that the lesions were in the anterior or posterior region of the trained cortex (see Fig. 1 for the locus of the lesions).

The animals with lesions in the medial cortex took almost as many trials to relearn (13.5 trials) as in the first learning. In contrast, the animals with anterior or posterior lesions showed significant $(P<0.05$; all statistics are two-tailed rank tests) savings, reaching criterion in 4.2 and 5.1 trials, respectively. (There were no differences between groups in original learning in this or subsequent experiments.)

These results support the suggestion that some of the learning involved in the avoidance task is stored in the medial cortex of the trained hemisphere, but of course, they are not conclusive since the lesions may have interfered with recall rather than removing the stored information. 
Table 1. The effect of a lesion in the anterior, medial, or posterior cortex of the trained hemisphere on the retention of an avoidance response. Both the first learning and the retention test are given while one cortex has spreading depression

\begin{tabular}{lccc}
\hline & & \multicolumn{2}{c}{ Mean trials to learn } \\
\cline { 3 - 4 } Locus of lesion & $N$ & $\begin{array}{c}\text { First } \\
\text { learning }\end{array}$ & $\begin{array}{c}\text { Retention } \\
\text { test }\end{array}$ \\
\hline Anterior & 6 & $12.3 \pm 4.2$ & $4.2 \pm 2.8^{*}$ \\
Medial & 10 & $14.4 \pm 6.4$ & $13.5 \pm 5.9$ \\
Posterior & 6 & $13.0 \pm 2.7$ & $5.1 \pm 2.3^{*}$ \\
\hline
\end{tabular}

* Significantly different from first learning $(P<0.05)$.

\subsection{Injecting the tissue from the trained cortex}

To test the possibility that the memory of the avoidance response is chemically coded, the tissue from the medial region of the trained cortex was removed and intraperitoneally injected back into the same animal. The line of reasoning behind this procedure was that when the tissue which is thought to contain the learning is injected, some of the molecules which code the learning may enter the blood vessels and be transported to and into the brain. The molecules are assumed to be structurally labelled with respect to their region of origin in the brain (medial cortex) so that once in the brain they are absorbed and alter only the similarly labelled cells in the homotopic region of the untrained cortex.

There are, of course, many assumptions in this argument, but those that make it most "biologically unlikely" concern the possibility of getting the molecules into the brain and to the right spot. The main obstacle to getting the molecules into the brain is the bloodbrain barrier, and there is evidence that some kinds of large molecules (antibodies) can get through [19]. In addition, the lesion in the trained hemisphere will disturb the blood-brain barrier and should greatly increase the ease of penetration into the brain [11]. As to getting the molecules to the right spot, this seems to require the assumption that the molecules are labelled, but there is evidence that this kind of labelling can occur and that such molecules could migrate to specific regions of the brain. This is shown most clearly in an experiment where antibodies formed to a specific brain tissue (caudate nucleus) and injected intraventricularly, subsequently attacked and disturbed only this specific structure [12].

Two groups of 15 animals each were trained on the avoidance task with one hemisphere depressed and on the following day, the medial cortex of the trained hemisphere was removed. In the experimental group, this tissue was intraperitoneally injected back into the donor animal as soon as the surgery was complete; in the control group, there was no injection. Both groups of animals were tested the following day for savings in relearning with the trained hemisphere depressed.

The results are clear (Table 2). The animals injected with the tissue from the medial cortex relearning significantly faster $(5.0$ trials, $P<0.01)$ than in the first learning. They also learned faster than the no-injection control group $(18.8$ trials, $P<0.01)$ which was slightly slower than in the first learning. To control for the possibility that the faster learning in the experimental group was due to the injection of the cortical tissue but not specifically to the medial tissue where the learning is thought to be stored, another control 
group was injected with tissue from the posterior region of the trained cortex (Fig. 1). In this group, relearning required 12.1 trials, not significantly better than the first learning or the control group with no injection.

Table 2. The effect of injecting tissue from the medial region of the trained cortex on relearning with the untrained hemisphere

\begin{tabular}{lccc}
\hline & \multicolumn{2}{c}{ Mean trials to learn } \\
\cline { 3 - 4 } Group & $N$ & $\begin{array}{c}\text { First } \\
\text { learning }\end{array}$ & $\begin{array}{c}\text { Relearning with } \\
\text { untrained hemisphere }\end{array}$ \\
\hline $\begin{array}{c}\text { Medial lesion, } \\
\text { tissue injected }\end{array}$ & 15 & $18.4 \pm 5.0$ & $5.0 \pm 1.9^{*}$ \\
$\begin{array}{c}\text { Medial lesion, } \\
\text { no injection }\end{array}$ & 15 & $15.4 \pm 7.1$ & $16.7 \pm 5.8$ \\
$\begin{array}{c}\text { Posterior lesion, } \\
\text { tissue injected }\end{array}$ & 8 & $15.9 \pm 7.9$ & $12.1 \pm 4.4$ \\
$\begin{array}{c}\text { Medial lesiont, } \\
\text { tissue injected }\end{array}$ & 8 & $15.4+4.8$ & $7.4+2.9 \pm$ \\
$\begin{array}{c}\text { Medial lesion } \dagger, \\
\text { no injection }\end{array}$ & 8 & $17.4 \pm 5.3$ & $13.1 \pm 6.3$ \\
\hline
\end{tabular}

* Significantly different from first learning $(P<0.01)$.

$\dagger$ Groups run blind.

$\ddagger$ Significantly different from first learning $(P<0.05)$.

To control for experimenter bias as a source of error, the medial injection group and the no-injection control group were repeated blind. The results were the same (Table 2): the animals $(N=8)$ injected with the tissue from the medial cortex of the trained hemisphere showed significant savings in relearning (7.4 trials) while the no-injection group $(N=8)$ did not (13.1 trials, $P<0.05)$.

The results support the hypothesis that at least part of the memory of the avoidance response is chemically stored in the medial cortex and that when the coded molecules are removed and injected back into the same animal, they can alter the untrained hemisphere so as to make relearning faster.

\subsection{The specificity of the injection effect}

In order to show more conclusively that the effect of the injected tissue is to actually transfer chemically stored information rather than to simply facilitate learning or performance in general, a slightly different task was given on the relearning day. In this new task, an animal which had previously learned to avoid the white side was put down just over the middle of the box onto the white side (see Fig. 2). The animal now had a choice; it could avoid the shock by running to the black side as previously learned or by running into the far half of the white side. If the effect of the injected tissue from the trained cortex is not specific, about the same number of injected and uninjected animals should learn each response; but if, instead, the injected material actually carries information about the previous learning to the untrained hemisphere, the injected animals should show a greater tendency to relearn the previously acquired task. 


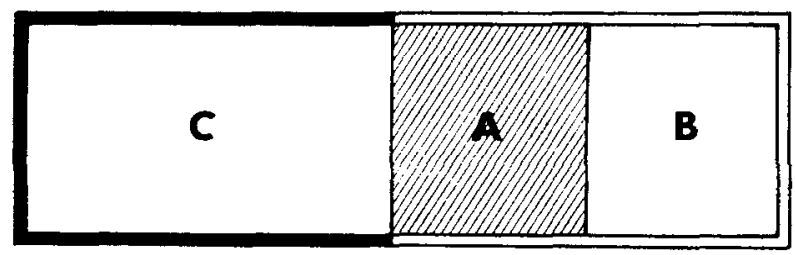

Fig. 2. The floor plan of the modified avoidance apparatus used in testing the specificity of the savings effect. The animal is put down in zone $A$ and can avoid shock by moving to the white (B) or black (C) end.

One hemisphere was depressed and the animals trained to avoid the white side; on the following day, the tissue from the medial cortex of the trained hemisphere was removed and injected back into the animals of the experimental group but not those of the control group. The next day, the trained hemisphere was depressed and the animals were trained on the modified avoidance task in which they could avoid shock by moving to the black side or to the end of the white side (Fig. 2). The procedure was the same as in the first training with several exceptions: the animals were put down in the white side, half facing the black and half facing the white side; when the animal chose the white side, the partition separating the black and white sides was not replaced during the intertrial interval, and in order for the movement to be considered a response, the animal had to remain in that end for at least $15 \mathrm{sec}$; the animal was required to reach a criterion of 7 out of 8 consecutive trials to one side without shock instead of 9 out of 10 .

The results (Table 3): the animals that were injected with the lesioned tissue all (8) moved to the side of the box (black) that had been safe during the first learning. In the uninjected group, only 3 out of the 8 animals chose this side; the others went to the end of the white side.

Table 3. The effect of injecting the cortical tissue from the trained hemisphere on the animal's choice of approaching the previously avoided or approached sides. The trained hemisphere is depressed during the choice test

\begin{tabular}{lcc}
\hline & \multicolumn{2}{c}{$\begin{array}{c}\text { Number of animals avoiding } \\
\text { each side in relearning }\end{array}$} \\
\cline { 2 - 3 } Group & Black & White \\
\hline $\begin{array}{l}\text { First trained to avoid white side } \\
\text { Injected } \\
\text { Uninjected }\end{array}$ & 0 & $8^{*}$ \\
First trained to avoid black side & 5 & 3 \\
Injected & & \\
Uninjected & 7 & $1^{*}$ \\
\hline & 2 & 5 \\
\hline
\end{tabular}

To control for any side preferences, the experiment was repeated with the white side safe during the first learning. The results were the same. Seven out of eight injected animals went to the white side compared to 2 out of 7 uninjected animals. 
It is clear that the animals injected with the tissue from the trained cortex chose to relearn the previously learned task more frequently than the uninjected animals $(P<0.01$; combined groups). This seems to show that specific chemically coded information about the learned avoidance response is transferred to the untrained hemisphere by molecules in the injected tissue.

\subsection{The length of the "consolidation" period}

Since the evidence up to this point strongly supported the conclusion that the memory of the avoidance response is chemically coded, additional experiments were done to relate the molecules causing the savings to existing evidence and intuitive requirements for a molecular information storage system. The first of these experiments considers the length of time following training required for the formation of the molecules mediating the savings. If these molecules are a part of the permanent information storage system in the brain, there should be a consolidation, or fixation, period of several hours after training before the synthesis is complete.

The animals were trained with one hemisphere depressed and then at varying times afterward, the medial cortex of the trained hemisphere was removed and injected back into the donor animal. Twenty-four hours later, the trained hemisphere was depressed and the animals were tested for savings in relearning.

The results are shown in Fig. 3. When the tissue from the trained cortex was removed at 2 or $4 \mathrm{hr}$ after training, the injection did not give rise to savings in relearning (13.5 and 12.6 trials, respectively). By about $7 \mathrm{hr}$, however, there was significant savings (6.2 trials, $P<0.05)$ and the amount was not significantly less than that of a 24 -hr group (5.2 trials). (The 2- and 24-hr groups were run blind. The first learning scores for these groups were 13.8 and 15.0 trials, respectively; the relearning of the $24-\mathrm{hr}$ group was significantly $[P<0.05]$ faster than that of the 2 -hr group.)

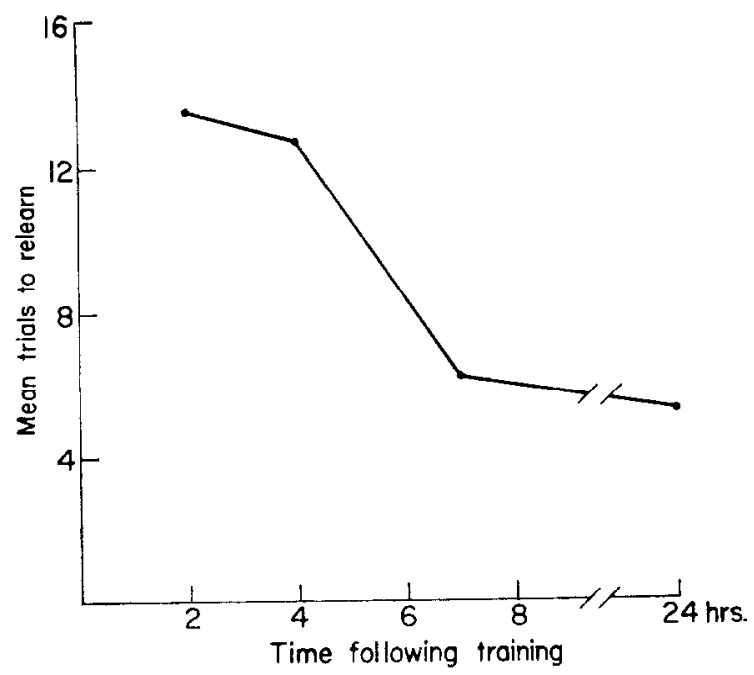

FIG. 3. The number of trials required to relearn when the injected tissue from the trained cortex is removed at varying times following training. The average scores of 6 animals determine each point. The 2- and 24-hr groups were run blind. 
A period of over $4 \mathrm{hr}$ following training is required for the formation of the molecules mediating the savings in relearning. This interval is somewhat longer than the 1-2 hr period that has generally been found for the consolidation of learning, but approaches very closely the 5-10 hr interval that ALBERT [3], using a new method, has obtained. The finding of an appropriate "consolidation period" for the savings effect clearly suggests that the molecules mediating the savings are a part of the permanent information storage system that is formed following learning.

\subsection{Intracellular origin of the molecules mediating the savings}

One would expect that as with other biological functions, information storage in the nervous system would be associated with a particular place or structure. The grossest physical localization of the critical molecules that could be made with the present preparation would be with respect to the cortical layers and the kind of cell, neuron or glia, but these experiments pose numerous difficulties and so were postponed. An equally important experiment is the subcellular localization of the active molecules within the cortical tissue and this is a comparatively simple problem using the well-known technique of differential centrifugation $[9,17]$.

Following some preliminary experiments which indicated that the active molecules were in the cell nuclei, the following experiment was carried out blind. The animals were first trained; the medial region of the trained cortex was then removed, and the tissue homogenized in ice cold $0.25 \mathrm{M}$ sucrose. The cell nuclei were separated from the homogenate by centrifugation (see Method) and suspended in $0.25 \mathrm{M}$ sucrose. Half the animals (6) were injected with the nuclei and half with the rest of the cellular homogenate. The next day the trained hemisphere was depressed and the animals were tested for savings in relearning.

Table 4 shows the results. The animals injected with the isolated nuclei showed savings in relearning ( 8.4 trials) while the animals injected with the rest of the homogenate did not $(12.3$ trials, $P<0.05)$.

Table 4. The effect of injecting various parts of the tissue from the medial region of the trained cortex on the relearning of the untrained hemisphere

\begin{tabular}{lccc}
\hline & & \multicolumn{2}{c}{ Mean trials to learn } \\
\cline { 3 - 4 } $\begin{array}{l}\text { Fraction of } \\
\text { tissue homogenate }\end{array}$ & $N$ & $\begin{array}{c}\text { First } \\
\text { learning }\end{array}$ & $\begin{array}{c}\text { Relearning with } \\
\text { untrained hemisphere }\end{array}$ \\
\hline Cell nuclei* & 6 & $13.0 \pm 1.7$ & $8.4 \pm 2.4 \dagger$ \\
$\begin{array}{l}\text { Homogenate minus } \\
\text { cell nuclei* }\end{array}$ & 6 & $12.5 \pm 2.2$ & $12.3 \pm 2.4$ \\
$\begin{array}{l}\text { Part of Cell Nuclei } \\
\text { Solid }\end{array}$ & 6 & $19.7 \pm 6.6$ & $4.3 \pm 1.8 \dagger$ \\
\begin{tabular}{l} 
Soluble \\
\hline
\end{tabular} & 6 & $12.4 \pm 1.0$ & $11.4 \pm 5.6$ \\
\hline
\end{tabular}

$\nmid$ Significantly different from first learning $(P<0.05)$.

* Groups run blind.

A sccond cxpcriment was done to determine whether the active molecules were in the solid or soluble portion of the cell nuclei. The method was to first isolate the nuclei and break them open by suspending them in distilled water. The solid material was then 
separated into a pellet by centrifuging at high speed (see Method). The pellet of solid material was suspended in distilled water and injected into half the animals and the soluble material (the supernatant) was injected into the others. The animals were tested for savings in relearning with the untrained hemisphere the following day.

Savings in relearning (Table 4) was shown by the group injected with the solid nuclear material ( 4.3 trials) but not the group injected with the soluble portion ( 11.4 trials, $P<0.05$ ).

The results seem clear: the critical molecules for the savings effect are located in the solid material of the nucleus, presumably the nucleolus. Although this conclusion may appear somewhat uncertain in view of expected cytoplasmic contamination of the isolated nuclei [9], the nuclear material, as isolated, appears to contain the full savings effect and the only subcellular particle which would be almost entirely present there are the nuclei.

\subsection{Characteristics of the molecules mediating the savings}

The chemical characteristics of the molecules which seem to be storing and transferring the learned response are examined in this final group of experiments. These begin by testing the possibility that the chemical is a macromolecule since this would seem to be necessary to both code the learning and allow selective migration to a specific region of the brain.

In the first experiment, the cortical tissue was heated in a water bath at $100^{\circ} \mathrm{C}$ for $10 \mathrm{~min}$, which is enough heat to destroy the structure and biological activity of most large molecules. The homogenate was then cooled and injected back into the donor animal.

These animals $(N=6)$ did not show savings in relearning with the untrained hemisphere (16.8 trials; Table 5), which supports the hypothesis that a macromolecule is mediating the savings effect.

Table 5. The effect of changing the injected cortical tissue in various ways on the savings in relearning with the untrained hemisphere

\begin{tabular}{lccc}
\hline & & \multicolumn{2}{c}{ Mean trials to learn } \\
\cline { 2 - 4 } Treatment & $N$ & $\begin{array}{c}\text { First } \\
\text { learning }\end{array}$ & $\begin{array}{c}\text { Relearning with } \\
\text { untrained hemisphere }\end{array}$ \\
\hline Heat $\left(100^{\circ} \mathrm{C}\right)$ & 6 & $16.7 \pm 7.0$ & $16.8 \pm 4.0$ \\
Cross animals & 5 & $16.8 \pm 7.1$ & $16.4 \pm 7.2$ \\
$\begin{array}{l}\text { Incubation in: } \\
\text { Ribonuclease }\end{array}$ & 6 & $17.2 \pm 7.2$ & $15.2 \pm 5.9$ \\
Trypsin & 4 & $15.8 \pm 4.4$ & $3.8 \pm 1.1^{*}$ \\
$0.9 \% \mathrm{NaCl}$ & 3 & $21.3 \pm 5.4$ & $4.0 \pm 0.8^{*}$ \\
\hline
\end{tabular}

* Combined groups, significantly different from first learning $(P<0.05)$.

$\Lambda$ second experiment considers the effect of injecting the tissue across animals. It seemed possible that the macromolecular coding of the learning might be chemically specific to each animal, or that the macromolecules mediating the effect might be destroyed 
as a foreign substance when injected across animals. The procedure was simply to inject the tissue from the trained cortex of one animal into another animal which had also been trained and lesioned.

When these animals $(N=5)$ were tested the following day with the trained hemisphere depressed, there was no savings in relearning (16.4 trials, Table 5).

This result also suggests that a large organic molecule is mediating the chemical transfer of learning.

To establish a preliminary identification of the specific kind of molecule mediating the savings, a final experiment was done using enzymes to selectively destroy either protein or ribonucleic acid. The tissue from the trained cortex was homogenized and the solid part of the cell nuclei isolated by centrifugation. This material was suspended in $6 \mathrm{ml}$ of a $0.9 \% \mathrm{NaCl}$ solution to which was added $1 \mathrm{mg} / \mathrm{ml}$ of trypsin (to break down protein) or $1 \mathrm{mg} / \mathrm{ml}$ ribonuclease (to break down ribonucleic acid). The suspensions were incubated for $60 \mathrm{~min}$ at $37^{\circ} \mathrm{C}$ in a water bath, cooled, and injected back into the donor animal. The animals were tested for savings in relearning the following day.

The results suggest that the critical molecule is a ribonucleic acid (Table 5) since the savings was blocked when the tissue was incubated in the ribonucleic acid destroying enzyme (15.2 trials, $N=6$ ). Destroying protein did not impair the savings in relearning (3.8 trials, $N=4)$ and these animals were about the same as a control group whose tissue was incubated in $0.9 \% \mathrm{NaC} 1$ alone (4.0 trials, $N=3$ ).

\section{DISCUSSION}

Injection of the tissue from the medial cortex of the trained hemisphere causes savings in relearning with the untrained hemisphere and there is a clear relation between the savings effect and the previous learning. The savings seems to be due to a specific tendency to perform the previously acquired response (Table 3 ), and the effect occurs only when the tissue is removed from the trained cortex after consolidation of the learning has progressed for several hours (Fig. 3). Further, the ribonucleic acid molecules which $5 \mathrm{ccm}$ to bc mediating the effect are located only at a specific site in the cell, the nucleus (Table 4). These results suggest that the effect of injecting the trained cortical tissue is to allow ribonucleic acid molecules which have coded the learned response to migrate to the untrained hemisphere and function there as stored learning.

On the basis of present knowledge about learning and information storage, the most important criticism of the present experiments seems to be that the effect of the injection may be to stimulate the natural interhemispheric transfer of the avoidance response in some way. The evidence, however, does not support this interpretation. For example, when the tissue from the medial cortex is removed, the animal can not recall the learning with the trained hemisphere (Table 1) so that it seems unlikely that there could be a spontaneous interhemispheric transfer of the learning. Also, there is no effect of the injection when the tissue is removed within $4 \mathrm{hr}$ after learning (Fig. 3). It is true that lesioning within about 1 or $2 \mathrm{hr}$ of training would cause cortical disturbances such as spreading depression which might interfere with consolidation taking place in other parts of the brain; however, these kinds of disturbances are known to be ineffective in interfering with the consolidation processes that occur during the next $2 \mathrm{hr}$ [3], and yet the removal and injection of the medial cortical tissue during this time still does not cause savings in relearning.

In addition, the conclusion that information is being transferred chemically is supported by the simultaneous discovery of evidence for interanimal chemical transfer of learning by 
Fjerdingstad, Nissen and RøigaARd-Petersen [7] and Babich, JACobson, Bubash and JACOBSON [4]. The failure to obtain interanimal transfer in the present experiments would seem to be due either to the possibility that the interanimal effects are smaller and, therefore, went unobserved, or that they occur only when the ribonucleic acid is isolated beforc being injected.

The evidence that chemically coded changes are involved in information storage in the mammalian nervous system is clearly important for the understanding of learning but it far from specifies the nature of the actual changes that occur. It does not rule out the possibility of synaptic changes which occur along with the nucleic acid change, particularly since there is considerable evidence that chemicals can determine synaptic connections [20]. However, in agreement with MorRELL [14], the present results suggest that it is unlikely that information is stored in multisynaptic pathways connecting separate areas of the brain. If this were the case, it would be necessary to conclude that in the present experiments, the injected material reaches specific cells and alters their connections. A more likely possibility would seem to be that certain areas of the brain are equipotential and that the injected molecules need only migrate to a certain region of the brain. This implies that the altered functional relations between parts of the brain following learning do not result from direct neural connections, but rather, that they may be effected through changes in the reception or emission of temporally patterned neural activity. (See Morrell [14], BrazIER [5], Hydén [10], and ADEY Dunlop, and Hendrix [1] for examples and evidence about the various forms such temporal activity might assumc.)

The biochemical characteristics of the storage mechanism are slightly clearer than the functional changes they cause. Since the ribonucleic acid molecules which seem to code the learning are in the nucleus, far from where they would directly affect electrochemical membrane changes, these molecules probably could not alter the behavior of neural cells directly. Rather, consistent with the other known functions of ribonucleic acid molecules as templates, it seems likely that here again their function would be to dictate the construction of molecules, such as protein, which actually effect the functional changes in the cell.

There is evidence that the injected ribonucleic acid in the present experiments could work this way. For example, it has been shown in biochemical experiments $[6,15,16]$ that ribonucleic acid can penetrate some kinds of cells and dictate the formation of particular proteins. Further, the evidence also indicates that the changes which this entering ribonucleic acid induces may be permanent since it seems to cause the cell nucleus to establish a biochemical process for permanently producing the new proteins [16].

Finally, these speculations and results on the nature of information storage are highly significant for experiments on the process of consolidation, or fixation, of learning. AlBERT [3] has suggested that during the one or two minutes following a lcarning trial, the molecules are formed (or released) that constitute the templates (or stimulants) for the rest of the consolidation process and that this is followed first by a physical chemical process and then by a process of biochemical synthesis. It now seems an interesting possibility that the physical chemical process may consist of a migration of the template molecules from their original position (perhaps at the neural axon hillock or dendritic membrane) to the cell nucleus and that the synthetic processes would consist of the formation of the appropriate nuclear ribonucleic acid and afterwards protein.

Acknowledgements-The author is indebted to the staff and students of the Neurochemistry Department of the Montreal Neurological Institute for help with some of the experiments. 


\section{REFERENCES}

1. Adey, W. R., Dunlop, C. W. and Hendrix, C. E. Hippocampal slow waves. A. M. A. Archs Neurol. 3, 74-90, 1960.

2. Albert, D. J. The effect of spreading depression on the consolidation of learning. Neuropsychologia 4, 49-64, 1966.

3. AlBERT, D. J. The effect of polarizing currents on the consolidation of learning. Neuropsychologia 4, 65-77, 1966.

4. BabiCh, F. R., JACOBSON, A. L., Bubash, S. and JACOBson, A. Transfer of a response to naive rats by injection of ribonucleic acid extracted from trained rats. Science, N.Y. 149, 656-657, 1965.

5. Brazier, M. A. B. Long-persisting electrical traces in the brain of man and their possible relationship to higher nervous activity. In Moscow Colloquium on Electroencephalography of Higher Nervous Activity, JASPER, H. H. and SMIRNOV, G. D. (Editors), Electroenceph. clin. Neurophysiol. suppl. 13, 347-358, 1960.

6. Cohen, E. P. and PARks, J. J. Antibody production by nonimmune splcen cells incubated with RNA from immunized mice. Science, N.Y. 144, 1012-1013, 1964.

7. Fjerdingstad, E. J., Nissen, Th. and Roigaard-Petersen, H. H. Effect of RNA extracted from the brain of trained animals on learning in rats. Scand. J. Psychol. 6, 1-6, 1965.

8. HeBB, D. O. The Organization of Behavior. Wiley, New York, 1949.

9. Hogeboom, G. H. Fractionation of cell components of animal tissues. In Methods in Enzymology, Vol. 1, Colowick, S. P. and KaPlan, N. O. (Editors), pp. 16-19, Academic Press, New York, 1955.

10. HYDÉN, H. Biochemical changes in glial cells and nerve cells at varying activity. In Biochemistry of the Central Nervous System, Vol. 3, Proc. 4th Intern. Congr. Biochem., Brucke, F. (Editor), pp. 64-89, Pergamon Press, London, 1959.

11. Lajtha, A. The "brain barrier system". In Neurochemistry, Elliott, K. A. C., PAGE, I. H. and Quastel, J. H. (Editors), pp. 399-430, Thomas, Springfield, 2nd edition, 1962.

12. Mihailovic, LJ. and JANKOviC, B. D. Effects of intraventricularly injected anti-n. caudatus antibody on the electrical activity of the cat brain. Nature, Lond. 192, 665-666, 1961.

13. Milner, P. M. Learning in neural systems. In Self-Organizing Systems. Yovits, M. C. (Editor), pp. 190-200, Pergamon Press, New York, 1959.

14. Morrell, F. Effect of anodal polarization on the firing pattern of single cortical cells. Ann. N. Y. Acad. Sci. 92, 860-876, 1961.

15. NiU, M. C., Cordova, C. C. and NiU, L. C. Ribonucleic acid-induced changes in mammalian cells. Proc. natl Acad, Sci. U.S.A. 47, 1689-1700, 1961.

16. NiU, M. C., Cordova, C. C., Niu, L. C. and Radbill, C. L. RNA-induced biosynthesis of specific enzymes. Proc. natl Acad. Sci. U.S.A. 48, 1964-1969, 1962.

17. Potter, V. R. Tissue homogenates. In Methods in Enzymology, Vol. 1, Colowick, S. P. and KAPLAN, N. O. (Editors), pp. 10-15, Academic Press, New York, 1955.

18. RANK, J. B. Synaptic "learning" due to electroosmosis: A theory. Science, N. Y. 144, 187-189, 1964.

19. Sherwin, A. L., Richter, M., Cosgrove, J. B. R. and Rose, B. Studies of the blood-cerebrospinal fluid barrier to antibodies and other proteins. Neurology 13, 113-119, 1963.

20. Sperry, R. W. Problems in the biochemical specification of neurons. In Biochemistry of the Developing Nervous System, WAELSCH, H. (Editor), pp. 74-84, Academic Press, New York, 1955.

21. Zelman, A., KABAT, L., JACOBSON, R. and MCCONNELl, J. V. Transfer of training through injection of "conditioned" RNA into untrained planarians. Worm Runner's Digest 5, 14-19, 1963.

Résumé-Chez des rats l'apprentissage d'une réponse d'évitement était limité à un hémisphère grâce à l'établissement d'une dépression corticale envahissante sur l'autre hémisphère. L'ablation de la partie moyenne du cortex (mais ni celle de la partie antérieure, ni celle de la partie postérieure) de l'hernisphère entrainé perturbe la rétention de apprentissage. Si le tissu enlevé est injecté dans le péritoine de l'animal donneur, se produit alors une préservation du répprentissage par l'hémisphère non entrainé. Cette préservation semble spécifique de la tâche antérieurement apprise et l'effet ne survient seulement que lorsque l'ablation du tissu de l'hémisphère entrainé a lieu après consolidation de l'apprentissage pendant plusieurs heures. Les molécules d'acide ribonucléique localisés dans le noyau de quelques groupe de cellules corticales semblent transmettre cet effet de préservation. Ces résultats suggérent qu'en injectant le tissu pris sur le cortex entrainé on permet aux molécules d'acide ribonucléique qui ont codé l'information concèrnant la réponse apprise d'émigrer sur l'hémisphère non entrainé et d'y fonctionner comme apprentissage stocké. 
Zusammenfassung -Die feste Verankerung einer Vermeidensreaktion wurde im Rahmen von Rattenversuchen auf eine Hemisphäre beschränkt, indem die andere Hälfte mit Hilfe einer diffusen Amplitudensenkung des Cortex dafür blockiert wurde. Die Fixierung von Lernstoff hörte sofort auf, wenn man den medialen Cortexteil der geübten Hemisphäre operativ beseitigte. (Dieses Ergebnis blieb bei Entfernung vorderer oder hinterer Bereiche aus.) Wenn man hinterher das entfernte Hirngewebe wieder bei dem gleichen Versuchstier intraperitoneal injizierte, so wurde dieses wieder fähig, mit seiner untrainierten Hirnhemisphăre Lernstoff aufzunehmen. Dieses Wiedergewinnen der Lernfähigkeit schien für die vorher geübten Aufgaben speziell erleichtert zu sein. Diesen positiven Effekt erzielte man aber nur dann, wenn man das Gewebe des geübten Cortexbereiches erst zu einem Zeitpunkt entnahm, nachdem der fixierende Lernprozess bereits einige Stunden in Gang war. Demnach scheinen Ribonucleinsäuremoleküle bestimmter Kerne corticaler Zellen făhig zu sein, einen Speicherungseffekt zu vermitteln. Diese Resultate scheinen dafür zu sprechen, dass die Wirkung der Gewebsinjektion trainierter Cortexanteile darauf beruht, dass mit Hilfe der Ribonucleinsäuremoleküle, welche vorher die erlernte Antwort codifiziert speicherten, eine Information an die untrainierte Hemisphäre durch Einwanderung der Moleküle weitergegeben und damit die Lernfähigkeit erleichtert wird. 